\title{
MENINGKATKAN KEMAMPUAN KOMUNIKASI MATEMATIK SISWA SEKOLAH MENENGAH PERTAMA MELALUI PEMBELAJARAN THINK-TALK-WRITE (TTW)
}

\author{
Oleh: \\ Nunun Elida \\ Guru Bidang Studi Matematika SMA Negeri 2 Cimahi \\ nunun@wahyurock.com
}

\begin{abstract}
Penelitian ini merupakan kuasi eksperimen berbentuk kelompok kontrol pretes-postes, dengan perlakuan pendekatan pembelajaran Think-Talk-Write (TTW) dan pembelajaran konvensional. Berdasarkan hasil analisis data, diperoleh kesimpulan bahwa peningkatan kemampuan komunikasi matematik siswa yang memperoleh pembelajaran dengan kooperatif Think-Talk-Write (TTW) lebih baik daripada siswa yang memperoleh pembelajaran dengan cara konvensional.
\end{abstract}

Kata kunci : komunikasi matematik, Think-Talk-Write (TTW)

This research is a form of quasi-experimental pretest-posttest in controlling group, which is using both of the cooperative learning approach of Think-Talk-Write (TTW) and the conventional learning. Based on the results of data analysis, it is concluded that the improvement of mathematical communication abilities of students who received cooperative learning with Think-Talk-Write (TTW) is better than the students who received the conventional learning.

Keywords: mathematical communication, Think-Talk-Write (TTW)

\section{Pendahuluan}

Matematika sebagai ilmu dasar mempunyai peranan sangat penting untuk mencapai keberhasilan pembangunan dalam segala bidang. Pernyataan tersebut berlandaskan pada asumsi bahwa penguasaan matematika akan menjadi sarana yang ampuh untuk mempelajari mata pelajaran lain, baik pada jenjang pendidikan yang sama maupun pada jenjang pendidikan yang lebih tinggi. Hal di atas didukung oleh hasil penelitian selama 15 tahun terakhir di Indonesia, menunjukkan bahwa prestasi belajar dalam mata pelajaran matematika berkorelasi positif dengan prestasi belajar dalam mata pelajaran lain, baik pelajaran eksakta maupun non eksakta (Fitrie, 2002:2). Hal ini sesuai dengan yang dikemukakan oleh Sujono, bahwa matematika merupakan alat yang efisien dan diperlukan oleh semua ilmu pengetahuan (Maria, 2000:11). 
Namun fakta di lapangan menunjukkan hasil belajar matematika siswa saat ini masih tergolong rendah (Maria, 2000:13). Hal ini berkaitan erat dengan anggapan bahwa matematika masih dianggap sebagai salah satu mata pelajaran yang dianggap sulit, sehingga pada umumnya siswa tidak menyenanginya.

Ruseffendi (1988:388) juga menyatakan, bahwa bagian terbesar dari matematika yang dipelajari siswa di sekolah tidak diperoleh melalui eksplorasi matematik, tetapi melalui pemberitahuan. Menurut Sutiarno (Ansari, 2003:3), bahwa kondisi pembelajaran yang berlangsung dalam kelas membuat siswa pasif. Pendapat serupa juga dikemukakan oleh Marsigit (Darhim, 2004:2), bahwa dalam pelaksanaannya di dalam kelas, pembelajaran matematika masih cenderung didominasi dengan cara konvensional yang lebih terpusat pada guru.

Hasil studi sebelumnya di Kota Cimahi terhadap siswa SMP, kecenderungan mereka menganggap bahwa matematika adalah pelajaran yang sulit untuk dipelajari dan jika diperbolehkan mereka berusaha menghindar dari bidang studi matematika. Kecenderungan ini berakibat pada motivasi belajar matematika siswa sangat rendah. Salah satu faktor yang mengakibatkan Hal tersebut karena siswa cenderung tidak memiliki kesempatan berkomunikasi untuk mengajukan pertanyaan dan menanggapi permasalahan, baik kepada guru maupun kepada siswa lainnya. Karena sebenarnya dari kesempatan berkomunikasi siswa akan dapat menambah wawasan pengetahuannya yang lebih luas lagi.

Salah satu solusi dari permasalahan-permasalahan di atas adalah pembelajaran matematika di sekolah dengan menggunakan pendekatan pembelajaran Think-TalkWrite (TTW) yang diupayakan dapat membuat siswa aktif serta berkomunikatif dalam proses belajar-mengajar pada mata pelajaran matematika. Melalui keterlibatan siswa secara aktif tersebut, maka diharapkan kemampuan komunikasi matematik siswa akan dapat terlatih dengan baik.

\section{Rumusan Masalah}

Berdasarkan latar belakang masalah di atas, rumusan masalah dalam penelitian ini adalah: "Apakah peningkatan kemampuan komunikasi matematik siswa memperoleh pembelajaran dengan Pendekatan Think-Talk-Write (TTW) lebih baik daripada siswa yang memperoleh pembelajaran dengan cara biasa?"

\section{Manfaat Penelitian}

Dengan diadakannya penelitian ini, diharapkan dapat bermanfaat :

1. Bagi siswa, penerapan pembelajaran dengan Pendekatan Think-Talk-Write (TTW) sebagai salah satu sarana untuk melibatkan aktivitas siswa secara optimal dalam memahami konsep matematika sehingga konsep yang semula abstrak akan lebih cepat dipahami secara terintegrasi. Serta membut situasi belajar siswa menjadi bermakna. 
2. Bagi peneliti, merupakan pengalaman yang berharga sehingga dapat dijadikan bahan pertimbangan untuk mengembangkan kemampuan komunikasi matematik pada berbagai jenjang pendidikan.

\section{Kemampuan Komunikasi Matematik dan Think-Talk-Write (TTW)}

\section{Kemampuan Komunikasi Matematik}

Menurut TIM (2003:256), 'Komunikasi adalah pengiriman dan penerimaan pesan antara dua orang atau lebih sehingga pesan yang dimaksud dapat dipahami'. Menurut Abdulhak (Ansari, 2003:3), 'Komunikasi dimaknai sebagai proses penyampaian pesan dari pengirim pesan kepada penerima pesan melalui saluran tertentu untuk tujuan tertentu'.

Untuk mengembangkan kemampuan berkomunikasi, orang-orang dapat menyampaikan informasi dengan bahasa matematika. Depdiknas (2001 : 8) menyatakan bahwa mengkomunikasikan gagasan dengan bahasa matematika justru lebih praktis, sistematis dan efisien. Lindquist (NCTM, 1989:2) berpendapat bahwa jika kita sepakat bahwa matematika merupakan suatu bahasan dan bahasa tersebut sebagai bahasa terbaik dalam komunitasnya, maka mudah dipahami bahwa komunikasi merupakan esensi dari mengajar, belajar dan mengakses matematika.

Hal ini sejalan dengan pendapat Huinker dan Laughlin (Hulukati, 2005:5) menyebutkan bahwa salah satu tujuan yang ingin dicapai dalam pembelajaran matematika adalah memberikan kesempatan seluas-luasnya kepada para siswa untuk mengembangkan dan mengintegrasikan keterampilan berkomunikasi melalui lisan maupun tulisan serta mempresentasikan apa yang telah dipelajari. Dengan komunikasi, baik lisan maupun tulisan dapat membawa siswa pada pemahaman yang mendalam tentang matematika dan dapat memecahkan masalah dengan baik.

NCTM (1989 : 214) menyatakan bahwa kemampuan komunikasi siswa dalam pembelajaran matematika dapat dilihat dari (1) Kemampuan mengekspresikan ideide matematika melalui lisan, tertulis, dan mendomonstrasikannya serta menggambarkannya secara visual; (2) Kemampuan memahami, menginterpretasikan, dan mengevaluasi ide-ide matematika baik secara lisan, tulisan, maupun dalam bentuk visual lainnya; (3) Kemampuan dalam menggunakan istilah-istilah, notasi-notasi matematika dan struktur-strukturnya, untuk menyajikan ide-ide, menggambarkan hubungan-hubungan dan model-model situasi.

Sedangkan menurut Sumarmo (2002 : 15) komunikasi matematik meliputi kemampuan siswa : (1) Menghubungkan benda nyata, gambar, dan diagram ke dalam ide matematika; (2) Menjelaskan ide, situasi dan relasi matematik, secara lisan dan tulisan dengan benda nyata, gambar, grafik dan aljabar; (3) Menyatakan peristiwa sehari-hari dalam bahasa atau simbol matematika; (4) Mendengarkan, berdiskusi, dan menulis tentang matematika; (5) Membaca dengan pemahaman suatu presentasi matematika tertulis; (6) Membuat konjengtur, menyusun argumen, 
merumuskan definisi dan generalisasi; (7) Menjelaskan dan membuat pertanyaan tentang matematika yang dipelajari.

Sementara itu, Schoen, Bean, dan Ziebarth (Ansari, 2003:16) mengemukakan bahwa kemampuan komunikasi matematik adalah kemampuan siswa dalam hal menjelaskan suatu algoritma dan cara unik untuk pemecahan masalah, kemampuan siswa mengkonstruksi dan menjelaskan sajian fenomena dunia nyata secara grafik, kata-kata atau kalimat, persamaan, tabel dan sajian secara fisik.

Berdasarkan literatur di atas, maka penulis dapat mendefinisikan kemampuan komunikasi matematik dalam penelitian ini adalah kemampuan siswa dalam menghubungkan benda nyata, gambar, dan diagram ke dalam ide matematika; menjelaskan ide, situasi dan relasi matematik baik secara lisan maupun tulisan dalam bentuk gambar atau grafik; menjelaskan serta membuat pertanyaan tentang matematika yang dipelajari dari suatu situasi yang diberikan.

\section{Think-Talk-Write (TTW)}

Pembelajaran TTW dimulai dengan bagaimana siswa memikirkan penyelesaian suatu tugas atau masalah, kemudian diikuti dengan mengkomunikasikan hasil pemikirannya melalui forum diskusi, dan akhirnya melalui forum diskusi tersebut siswa dapat menuliskan kembali hasil pemikirannya. Aktivitas berpikir, berbicara, dan menulis adalah salah satu bentuk aktivitas belajar-mengajar matematika yang memberikan peluang kepada siswa untuk berpartisipasi aktif. Melalui aktivitas tersebut siswa dapat mengembangkan kemampuan berbahasa secara tepat, terutama saat menyampaikan ide-ide matematika.

\section{a. Think}

Aktivitas berpikir (think) dapat dilihat dari proses membaca suatu teks matematika atau berisi cerita matematika. Dalam tahap ini siswa secara individu memikirkan kemungkinan jawaban (pendekatan penyelesaian), membuat catatan apa yang telah dibaca, baik itu berupa apa yang diketahuinya, maupun langkah-langkah penyelesaian dalam bahasanya sendiri.

Menurut Marzuki (2006 : 27) bahwa berpikir yang dilakukan manusia meliputi lima dimensi yaitu :

1) Metakognisi, merupakan kesadaran seseorang tentang proses berpikirnya pada saat melakukan tugas tertentu dan kemudian menggunakan kesadaran tersebut untuk mengontrol apa yang dilakukan.

2) Berpikir kritis dan kreatif, merupakan dua komponen yang sangat mendasar. Berpikir kritis merupakan proses penggunaan kemampuan berpikir secara efektif yang dapat membantu seseorang untuk membuat, mengevaluasi, serta mengambil keputusan tentang apa yang diyakini serta dilakukan. Sedangkan berpikir kreatif merupakan kemampuan yang bersifat spontan, terjadi karena adanya arahan yang bersifat internal dan keberadaannya tidak bisa diprediksi. 
3) Proses berpikir, memiliki delapan kompenen utama yaitu pembentukan konsep, pembentukan prinsip, pemahaman, pemecahan masalah, pengambilan keputusan, penelitian, penyusunan, dan berwacana secara oral.

4) Kemampuan berpikir utama, juga memiliki delapan komponen yang memfokuskan, kemampuan mendapatkan informasi, kemampuan mengingat, kemampuan mengorganisasikan, kemampuan menganalisis, kemampuan menghasilkan, kemampuan mengintegrasi, serta kemampuan mengevaluasi.

5) Berpikir matematik tingkat tinggi, pada hakekatnya merupakan non-prosedural yang antara lain mencakup hal-hal berikut : kemampuan mencari dan mengeksplorasi pola, kemampuan menggunakan fakta-fakta, kemampuan membuat ide-ide matematik, kemampuan berpikir dan bernalar secara fleksibel, serta menetapkan bahwa suatu pemecahan masalah bersifat logis.

\section{b. Talk}

Pada tahap talk, siswa berkomunikasi dengan menggunakan kata-kata dan bahasa yang mereka pahami. Siswa menyampaikan ide yang diperolehnya pada tahap think kepada teman-teman diskusinya (kelompok). Pemahaman dibangun melalui interaksinya dalam diskusi. Diskusi diharapkan dapat menghasilkan solusi atas masalah yang diberikan. Selain itu, pada tahap ini siswa memungkinkan untuk terampil berbicara.

Diskusi dapat menguntungkan pendengar yang baik, karena dapat memberi wawasan baru baginya. Baroody (Ansari, 2003:25) menguraikan beberapa kelebihan dari diskusi kelas, yaitu :

1) Dapat mempercepat pemahaman materi pembelajaran dan kemahiran menggunakan pendekatan.

2) Membantu siswa mengkonstruksi matematika.

3) Menginformasikan bahwa para ahli matematika biasanya tidak memecahkan masalah sendiri-sendiri, tetapi membangun ide bersama pakar lainnya dalam satu tim.

4) Membantu siswa menganalisis dan memecahkan masalah secara bijaksana.

\section{c. Write}

Aktivitas menulis berarti mengonstruksi ide, karena setelah berdiskusi antar teman kemudian mengungkapkannya melalui tulisan. Shield dan Swinson (Ansari, 2003:39) menyatakan, bahwa menulis dalam matematika membantu merealisasikan salah satu tujuan pembelajaran, yaitu pemahaman siswa tentang materi yang ia pelajari.

Aktivitas selama tahap ini adalah :

1) Menulis solusi terhadap masalah yang diberikan termasuk perhitungan.

2) Mengorganisasikan semua pekerjaan langkah demi langkah.

3) Mengoreksi semua pekerjaan sehingga yakin tidak ada pekerjaan yang tertinggal. 
4) Meyakini bahwa pekerjaannya lengkap, mudah dibaca dan terjamin keasliannya.

\section{Metode dan Prosedur Penelitian}

Penelitian ini merupakan penelitian kuasi eksperimen dengan disain penelitiannya sebagai berikut :

$$
\left.\begin{array}{lll}
O \quad X O & O \\
\hdashline O & O
\end{array} \quad \text { (Ruseffendi, } 2005: 53\right)
$$

Keterangan :

$\mathrm{O} \quad$ : Tes Kemampuan komunikasi matematik

X : Perlakuan dengan pendekatan pembelajaran TTW

Subyek populasi dalam penelitian ini adalah seluruh siswa kelas XI Sekolah Menengah Atas (SMA) di kota Cimahi. Kemudian dari sekolah tersebut diambil dua kelas sebagai sampel. Disamping skenario pembelajaran untuk pendekatan pembelajaran TTW, dalam penelitian ini digunakan Instrumen berupa tes kemampuan komunikasi matematik.

\section{Instrumen Penelitian}

Untuk memperoleh data dalam penelitian ini digunakan beberapa macam instrumen, yaitu seperangkat tes kemampuan komunikasi matematik. Untuk mengetahui seberapa besar peningkatan kemampuan komunikasi matematik siswa sebelum dan setelah kegiatan pembelajaran, dilakukan analisis skor gain ternormalisasi yang dihitung dengan menggunakan rumus sebagai berikut :

$$
\mathrm{g}=\frac{\text { skor tes akhir -skor tes awal }}{\text { skor maksimum ideal -skor tes awal }}
$$

Tingkat perolehan skor gain ternormalisasi dikelompokkan kedalam tiga kategori, yaitu :

$$
\begin{array}{lll}
0,70< & (\mathrm{g}) & : \text { Tinggi } \\
0,30 \leq & \mathrm{g}) \leq 0,70 & : \text { Sedang } \\
(\mathrm{g})<0,30 & : \text { Rendah }
\end{array}
$$

\section{VII.Analisis Data dan Pembahasan}

Deskripsi peningkatan kemampuan komunikasi matematik merupakan gambaran kualitas peningkatan kemampuan berpikir kritis matematik berdasarkan pendekatan pembelajaran (pendekatan pembelajaran TTW dan pendekatan pembelajaran KONV). Deskripsi yang dimaksud adalah rata-rata dan standar deviasi berdasarkan pendekatan pembelajaran yang ditampilkan pada Tabel 1 . 


\section{Tabel 1 \\ Deskripsi Data Gain Ternormalisasi \\ Peningkatan Kemampuan Komunikasi Matematik Siswa \\ Berdasarkan Pendekatan Pembelajaran}

\begin{tabular}{|c|c|c|c|c|c|}
\hline \multirow{2}{*}{$\begin{array}{c}\text { PENDEKATAN } \\
\text { PEMBELAJARAN }\end{array}$} & \multicolumn{2}{|c|}{ SKOR } & \multirow{2}{*}{ RERATA } & $\begin{array}{c}\text { SIMPANGAN } \\
\text { BAKU }\end{array}$ & KRITERIA \\
\cline { 2 - 6 } & MIN & MAX & & 0,16 & Sedang \\
\hline TTW & 0,31 & 0,93 & 0,64 & Sedang \\
\hline KONV & 0,21 & 0,72 & 0,47 & 0,14 & \\
\hline
\end{tabular}

Catatan: Skor Maksimum Ideal 1,00

Berdasarkan Tabel 1, dapat dikemukakan deskripsi perbandingan peningkatan kemampuan komunikasi matematik siswa secara keseluruhan berdasarkan jenis pendekatan pembelajaran (TTW dan KONV) adalah rerata 0,64 > 0,47; standar deviasi $0,16>0,14$; Hal ini menunjukkan bahwa peningkatan kemampuan komunikasi matematik siswa yang pembelajarannya menggunakan pendekatan TTW lebih baik daripada siswa yang pembelajarannya menggunakan cara konvensional.

Untuk mendukung deskripsi peningkatan kemampuan komunikasi matematik yang telah dijelaskan, maka dilakukan analisis data komunikasi matematik siswa melalui uji statistik dengan menggunakan uji perbedaan rata-rata dua kelompok sampel.

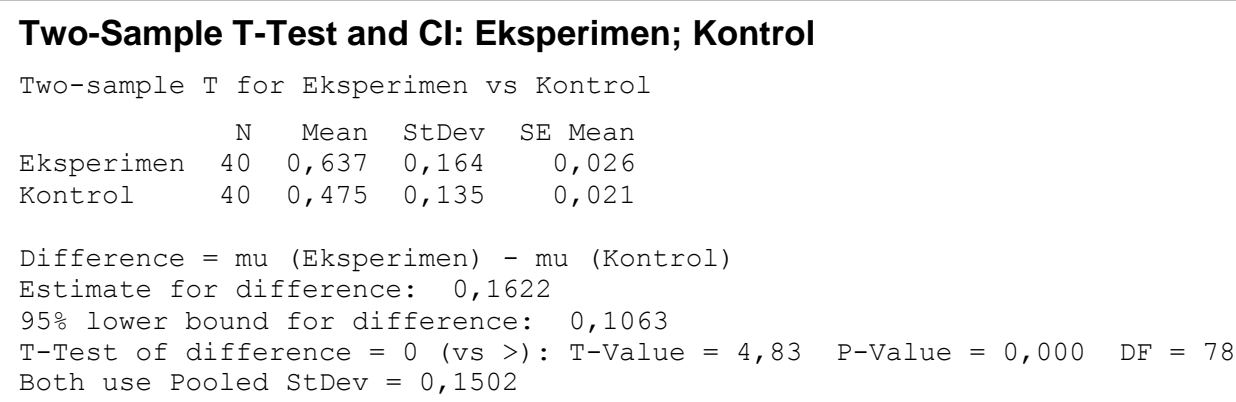

Sumber: output minitab 15

\section{Pendekatan Pembelajaran}

$$
\begin{aligned}
& \mathrm{H}_{0}: \mu_{e}=\mu_{k} \\
& \mathrm{H}_{\mathrm{A}}: \mu_{e}>\mu_{k}
\end{aligned}
$$

Kriteria pengujian :

Jika $P$-value $>0,05$ maka $\mathrm{H}_{0}$ diterima

Dari hasil output program minitab 15 , diperoleh nilai $P$-value $=0,000$; atau dengan kata lain $P$-value $<0,05$. Hal tersebut dapat disimpulkan bahwa kemampuan 
komunikasi matematik siswa yang pembelajarannya menggunakan pembelajaran TTW secara signifikan lebih baik daripada yang pembelajarannya menggunakan cara konvensional pada taraf signifikansi $5 \%$.

\section{Kesimpulan}

Berdasarkan analisis data diperoleh kesimpulan bahwa kemampuan komunikasi matematik siswa yang pembelajarannya menggunakan pembelajaran TTW secara signifikan lebih baik daripada yang pembelajarannya menggunakan cara konvensional pada taraf signifikansi $5 \%$.

\section{DAFTAR PUSTAKA}

Ansari, B. I. (2003). Menumbuhkembangkan Kemampuan Pemahaman dan Komunikasi Matematik Siswa Sekolah Menengah Umum (SMU) melalui Strategi Think Talk Write. Disertasi Doktor pada FPMIPA UPI Bandung: Tidak diterbitkan.

Darhim. (2004). Pengaruh Pembelajaran Matematika Kontekstual Terhadap Hasil Belajar dan Sikap Siswa Sekolah Dasar Kelas Awal dalam Matematika. Disertasi FPMIPA UPI Bandung: Tidak diterbitkan.

Depdiknas (2001). Standar Nasional. Silabus Matematika SLTP/MTs. Jakarta: Depdiknas

Fitrie, N. (2002). Pengembangan Kemampuan dan Komunikasi Matematika Siswa SLTP Melalui Aktivitas Berbicara, Mendengar, dan Menulis Matematika. Skripsi FPMIPA UPI Bandung: Tidak diterbitkan.

Hulukati, E. (2005). Mengembangkan Kemampuan Komunikasi dan Pemecahan Masalah Matematik Siswa SMP melalui Model Pembelajaran Generatif. Disertasi pada FPMIPA UPI. Bandung: Tidak diterbitkan.

Maria. (2000). Kontribusi Sikap Siswa SMU mengenai Nilai dan Edukasional Matematika Terhadap Prestasi Belajarnya Pada Pelajaran Matematika. Skripsi FPMIPA UPI Bandung: Tidak diterbitkan.

Marzuki, A. (2006). Implementasi Pembelajaran Kooperatif (Cooperative Learning) Dalam Upaya Meningkatkan Kemampuan Koneksi dan Pemecahan Masalah Matematik Siswa. Tesis pada PPS UPI. Bandung: Tidak diterbitkan.

NCTM. (1989). Curriculum and Evaluation Standard for School Mathematics. Virginia: The NCTM Inc.

Ruseffendi, E. T. (1988). Pengajaran Matematika Untuk Meningkatkan CBSA. Bandung: Tarsito.

Ruseffendi, E. T. (2005). Dasar-Dasar Penelitian Pendidikan dan Bidang Non-Eksakta Lainnya. Bandung: Tarsito

Sumarmo, U. dkk. (2002). Alternatif Pembelajaran Matematika dalam Menerapkan Kurikulum Berbasis Kompetensi. Makalah pada Seminar Tingkat Nasional FPMIPA UPI Bandung: Tidak Dipublikasikan.

TIM. (2003). Kamus Besar Bahasa Indonesia. Jakarta: Balai Pustaka. 